\title{
KEMAMPUAN BERPIKIR KREATIF MATEMATIS SISWA DAN MODEL PEMBELAJARAN PROBLEM SOLVING BERBASIS LESSON STUDY
}

\author{
Risnanosanti $^{1}$, Mardiah Syofiana ${ }^{2}$, Hasdelyati $^{3}$ \\ FKIP Universitas Muhammadiyah Bengkulu ${ }^{1,2}$ \\ SMP Negeri 18 Kota Bengkulu ${ }^{3}$ \\ risnanosanti@umb.ac.id ${ }^{1}$
}

\begin{abstract}
ABSTRAK
Penelitian ini bertujuan untuk meningkatkan kualitas proses pembelajaran matematika, untuk mengembangkan kemampuan berpikir kreatif matematis siswa, dan untuk mendapatkan hasil pembelajaran yang lebih baik dengan menerapkan model pembelajaran problem solving berbasis lesson study. Jenis penelitian ini adalah penelitian tindakan kelas yang melibatkan 32 siswa kelas VIII.2 SMP Negeri 18 Kota Bengkulu pada tahun ajaran 2019-2020. Pengumpulan data dilakukan dengan menggunakan tes dan wawancara. Data dianalisis dengan menggunakan metode deskriptif. Berdasarkan hasil analisis data diperoleh hasil sebagai berikut (1) model problem solving berbasis lesson study memberikan dampak positif terhadap kemampuan berpikir kreatif matematis siswa (2) proses pembelajaran yang dilakukan dapat meningkatkan hasil belajar siswa (3) meningkatkan kemampuan siswa untuk lebih memahami kegiatan pembelajaran dan kemampuan untuk menerapkan cara penyelesaian permasalahan dalam semua jenis masalah yang dihadapi, dan (4) meningkatkan aktivitas belajar siswa. Berdasarkan hasil penelitian ini, direkomendasikan untuk menerapkan model problem solving berbasis lesson study pada pokok bahasan ataupun mata pelajaran yang lainnya.
\end{abstract}

Kata kunci : berpikir kreatif, problem solving, lesson study

\begin{abstract}
This study aims (1) to improve the quality of the mathematics learning process, (2) to develop students' mathematical creative thinking abilities, and (3) to get better learning outcomes by applying lesson study based problem-solving learning models. This type of research is a classroom action research study involving 32 students of class VIII.2 SMP Negeri 18 Bengkulu in the 2019-2020 school year. Data collection was carried out using tests and interviews. Data were analyzed using descriptive methods. Based on the results of data analysis the following results are obtained (1) lesson study based problem-solving models have a positive impact on students 'mathematical creative thinking abilities (2) the learning process is undertaken can improve student learning outcomes (3) improve students' ability to better understand learning activities and the ability to apply ways of solving problems in all types of problems encountered, and (4) enhance student learning activities. Based on the results of this study, it is recommended to apply the lesson study-based problem-solving model on the subject or other subjects.
\end{abstract}

Keywords : creative thinking, problem solving, lesson study 


\section{PENDAHULUAN}

Salah satu komponen yang berperan penting pada pencapaian prestasi dalam pembelajaran matematika adalah dimilikinya kemampuan berpikir tingkat tinggi. Hal ini dikarenakan kemampuan berpikir tingkat tinggi merupakan suatu kemampuan untuk membuat keputusan dalam memecahkan permasalahan secara kritis dan kreatif (Sari dan Yuniarti, 2015). Upaya pemecahan masalah dilakukan dengan jalan menghubungkan, memanipulasi, serta mentransformasikan pengetahuan dan pengalaman yang telah dikuasai sebelumnya. Salah satu kemampuan berpikir tingkat tinggi yang harus dikuasai oleh siswa adalah kemampuan berpikir kreatif matematis. Kemampuan berpikir kreatif merupakan salah satu ciri dari kemampuan berpikir tinggi yaitu suatu kemampuan untuk berpikir logis dan divergen dalam membangun ide-ide baru yang didasari pada masalah yang menantang dan bersifat non-rutin.

Penelitian mengenai kemampuan berpikir kreatif matematis telah banyak dilakukan oleh para ahli diantaranya penelitian yang menunjukkan bahwa kemampuan berpikir kreatif matematis siswa dapat ditingkatkan, terutama dalam menyelesaikan masalah matematika, pemahaman dan komunikasi (Saragih dan Napitupulu, 2015; Yen dan Halili, 2015). Penelitian Sharma (2014) membahas tentang efek strategi dan kecemasan terhadap matematika, dan interaksinya pada kemampuan berpikir kreatif matematis siswa. Hasil penelitian ini menunjukkan bahwa strategi pengembangan kemampuan berpikir kreatif matematis lebih cocok untuk siswa yang mempunyai kecemasan terhadap matematika yang rendah daripada siswa dengan kecemasan tinggi. Penelitian lain yang dilakukan oleh Goodson, King, dan Rohani (2015) mengembangkan kemampuan berpikir tingkat tinggi siswa yang melibatkan kemampuan berpikir kreatif, sehingga dapat membuat siswa menghadapi tantangan dalam kehidupan sehari-hari. Hasil penelitian menunjukkan bahwa kemampuan berpikir kreatif siswa laki-laki lebih rendah dibandingkan dengan siswa perempuan. Selain itu beberapa hasil penelitian menunjukkan bahwa terdapat hubungan antara kemampuan berpikir kreatif matematis siswa dengan prestasi belajarnya secara keseluruhan (Risnanosanti, 2010; Anwar, Aness, dan Khizar, 2012; Saragih dan Napitupulu, 2015).

Oleh karena itu, pembelajaran matematika di sekolah harus memberi perhatian pada pengembangan kemampuan berpikir kreatif matematis siswa. Kemampuan berpikir kreatif matematis dapat menjamin perkembangan pengetahuan matematika siswa secara keseluruhan (Nuryanti, 2016; Nugraha dan Mahmudi, 2015; Sunaryo, 2014; Sriraman dan Lee, 2011; Risnanosanti, 2010). Pembelajaran yang dapat mengembangkan kemampuan berpikir kreatif matematis siswa menjadi tujuan dalam peningkatan kualitas pendidikan (Yen dan Halili, 2015).

Pada kegiatan pembelajaran di sekolah salah satu unsur yang memegang peranan penting adalah guru. Kemampuan berpikir kreatif matematis harus dilatih dan dikembangkan oleh guru dalam kegiatan pembelajaran di kelas. Guru dapat mendorong, menumbuhkan dan melatih siswa dalam mengembangkan kemampuan berpikir kreatif matematisnya. Guru harus mencoba dan menggunakan model pembelajaran yang tepat yang dapat menumbuhkan kemampuan berpikir kreatif matematis siswa. Salah satu usaha yang dapat dilakukan guru adalah dengan merencanakan lingkungan belajar yang mendukung kreativitas siswa (Newmann dan Wehlage, 1993; Shriki, 2010; Thomas dan Thorne, 2009). Kemampuan berpikir kreatif matematis harus dilatih dan dikembangkan oleh guru dalam kegiatan belajar mereka di ruang kelas. 
Oleh karena itu perlu dilakukan reorientasi dalam pemilihan model pembelajaran dan kualitas proses pembelajaran matematika di kelas. Salah satu model pembelajaran yang dapat dipilih adalah model pembelajaran problem solving. Beberapa alasan pemilihan model pembelajaran problem solving adalah: 1) Proses pembelajaran yang berpusat pada siswa atau students centre; 2) Peran guru dalam kegiatan pembelajaran sebagai fasilitator dan mediator; 3) intensitas aktivitas belajar siswa akan lebih tinggi; 4) Terjadi proses belajar lebih bermakna (meaningfull learning); 5) Permasalahan-permasalahan yang disajikan dalam pembelajaran akan berfungsi sebagai stimulus dalam melatih kemampuan berpikir kreatif matematis. Proses berpikir kreatif akan berpotensi melatih kemampuan berpikir kreatif matematis siswa. Aspek kreativitas ilmiah berupa problem finding, problem solving creating hyphotheses, design exsperiment dan product design (Ayas dan Sak, 2014; $\mathrm{Hu}$, Shi, Han, Wang, dan Adey, P. 2010). Informasi baru dapat diperoleh melalui belajar secara mandiri; dan 6) Masalah yang disajikan dalam proses pembelajaran merupakan wahana untuk mengembangkan keterampilan pemecahan masalah.

Model pembelajaran problem solving yang diterapkan pada penelitian ini dipadukan dengan kegiatan lesson study. Kegiatan pembelajaran berbasis Lesson study merupakan suatu upaya yang dilakukan oleh sekelompok guru untuk meningkatkan kompetensi dalam pembelajaran. Proses pembelajaran yang telah dilakukan dikaji secara berkelanjutan untuk meningkatkan kualitasnya secara kolaboratif dan berdasarkan prinsip-prinsip kolegialitas.

Lesson study memiliki tiga tahapan pelaksanaan, yaitu plan, do, dan see. Tahap plan, guru model merancang konsep rencana pembelajaran dan disajikan pada diskusi dengan kelompok guru untuk mendapatkan tanggapan dan usulan perbaikan. Tahap $d o$, guru model melaksanakan proses pembelajaran dan guru lain bertindak sebagai pengamat/observer. Pengamat/observer mencatat dengan cermat hal-hal terkait metode, media, dan alat bantu lain selama kegiatan pembelajaran berlangsung. Tahap see, kelompok guru mendiskusikan hasil pengamatan untuk memperbaiki proses pembelajaran berikutnya. Tahap ini bisa disebut refleksi dan pada akhirnya dapat meningkatkan kompetensi bersama-sama.

Pembelajaran dengan pola lesson study perlu dikembangkan sebagai suatu cara meningkatkan mutu pendidikan yang tak pernah berakhir (Hikmawati, Kesipuddin, dan Rahayu, 2018). Sehingga yang diharapkan dapat: 1) meningkatnya kemampuan berpikir kreatif siswa, 2) meningkatnya hasil belajar siswa, dan 3) meningkatnya aktivitas guru dan siswa pada proses pembelajaran matematika, dengan mengimplementasikan model pembelajaran problem solving dengan pola lesson study.

\section{METODE}

Jenis penelitian yang digunakan adalah penelitian tindakan kelas, yaitu kegiatan pembelajaran yang mengimplementasikan model pembelajaran problem solving berbasis lesson study. Subjek penelitian adalah siswa kelas VIII.2 SMP Negeri 18 Kota Bengkulu Tahun ajaran 2019/2020 yang berjumlah 32 orang. Penelitian ini dilakukan dengan mengikuti tahapan-tahapan kegiatan lesson study sebagai berikut: (1) tahap plan: tim lesson study merancang kegiatan permbelajaran, (2) tahap do: seorang guru model mengajar dan guru lainnya sebagai observer; (3) tahap see : guru model maupun observer bersama-sama merefleksi hasil 
pembelajaran. Penelitian dilaksanakan dalam dua siklus yaitu: siklus I, kegiatan pembelajaran dengan pokok bahasan kedudukan garis, kegiatan pembelajaran dengan pokok bahasan hubungan dua garis. Data dalam penelitian ini berbentuk data kuantitatif, yaitu skor nilai kemampuan berpikir kreatif matematis, skor nilai hasil belajar siswa, dan aktivitas siswa dalam pembelajaran. Skor nilai kemampuan berpikir kreatif matematis dan skor nilai hasil belajar siswa diukur dengan teknik tes, sedangkan aktivitas siswa diukur dengan lembar observasi. Kriteria kemampuan berpikir kreatif matematis menggunakan kriteria (Rahayu, Mulyani, dan Miswadi, 2012), seperti pada tabel 1 berikut.

Tabel 1. Kriteria kemampuan berpikir kreatif

\begin{tabular}{ccc}
\hline No & Persentase & Kriteria \\
\hline 1 & $68 \%-100 \%$ & Kreatif \\
2 & $67 \%-33 \%$ & Cukup kreatif \\
3 & $<33 \%$ & Kurang kreatif \\
\hline
\end{tabular}

Untuk melihat peningkatan kemampuan berpikir kreatif matematis siswa digunakan faktor g (gain factor) dari satu siklus ke siklus berikutnya. Menurut Cox dan Junkin (2002) gain factor dapat dirumuskan sebagai berikut:

$$
g=\frac{s_{f}-s_{i}}{s_{\max }-s_{i}}
$$

Dengan g adalah gain factor, Si skor awal, Sf skor akhir, dan Smax merupakan skor maksimum. Kualifikasi perolehan skor adalah sebagai berikut:

Tabel 2. Kriteria gain faktor

\begin{tabular}{ccc}
\hline No & Gain factor $(\mathrm{g})$ & Kriteria \\
\hline 1 & $\mathrm{~g}>0,70$ & Tinggi \\
2 & $0,30<\mathrm{g} \leq 0,70$ & Sedang \\
3 & $\mathrm{~g} \leq 0,30$ & Rendah \\
\hline
\end{tabular}

\section{HASIL DAN PEMBAHASAN}

\section{A. Hasil Penelitian Siklus I}

Sebelum melaksanakan kegiatan pembelajaran dengan model problem solving berbasis kegiatan lesson study, terlebih dahulu dilakukan observasi awal. Berdasarkan hasil observasi awal dapat diidentifikasi beberapa permasalahan yang muncul, yaitu bahwa strategi pembelajaran yang dipergunakan adalah strategi ekspositori dan tanya jawab. Strategi ini mengakibatkan kegiatan pembelajaran yang terjadi berpusat pada guru atau bersifat teacher centered, pengetahuan awal siswa seringkali diabaikan, siswa menjadi pasif. Kegiatan pembelajaran selalu diawali dengan guru memberikan informasi, sedangkan siswa kurang diberi kesempatan berkreasi untuk mengerjakan permasalahan yang diberikan. Sehingga siswa masih terfokus pada cara penyelesaian yang terdapat pada buku pegangan. 
Tahap plan, pada siklus I dilakukan kegiatan-kegiatan sebagai berikut: (1) Kelompok guru menyusun program pembelajaran untuk mata pelajaran matematika dengan mengimplementasikan model pembelajaran problem solving. Siswa diharapkan bisa menganalisis masalah, merencanakan penyelesaian yang akan dilakukan, mengerjakan perencanaan yang telah dibuat, dan mengecek hasil penyelesaian yang dilakukan; (2) Menetapkan permasalahan pada pokok bahasan kedudukan garis, dan permasalahan yang digunakan sebagai stimulus pembelajaran. Permasalahan yang diajukan ke siswa tentang kedudukan garis dengan berbagai cara menggunakan tayangan photo-photo berkaitan dengan kedudukan garis dalam kehidupan sehari-hari, sehingga kemampuan berpikir kreatif matematis siswa bisa terlihat dalam proses pembelajaran.

Tahap do, pada tahap pelaksanaan proses pembelajaran dan berdasarkan hasil tes baik pada tes awal maupun tes akhir di siklus I, sebagian besar penyelesaian permasalahan yang dilakukan oleh siswa masih belum terstruktur. Siswa tidak/kurang cermat dalam menganalisis permasalahan yang diberikan. Di samping itu, siswa cenderung kurang melakukan evaluasi kembali terhadap jawaban yang telah ditulis sehingga sering terjadi kesalahan dalam memperoleh hasil. Sedangkan kualitas proses pembelajaran diamati dalam bentuk aktivitas siswa dalam pembelajaran di kelas, seperti disajikan pada tabel 3 berikut.

Tabel 3. Aktivitas siswa dalam proses pembelajaran pada siklus I

\begin{tabular}{ll}
\hline \multicolumn{1}{c}{ Parameter } & \multicolumn{1}{c}{ Deskripsi } \\
\hline Mengerjakan tugas & $\begin{array}{l}\text { Semua kelompok mengerjakan tugas, tetapi masih ada } \\
\text { kelompok yang tidak serius mengerjakan tugas tersebut }\end{array}$ \\
\hline $\begin{array}{l}\text { Kerjasama dalam } \\
\text { kelompok }\end{array}$ & $\begin{array}{l}\text { Ada kelompok yang belum menunjukkan kerjasama } \\
\text { dengan baik. Hal ini dapat diidentifikasi berdasarkan } \\
\text { hasil pengamatan para observer pada saat diskusi } \\
\text { kelas. Penyajian hasil kerja kelompok hanya dilakukan } \\
\text { oleh salah satu anggota kelompok }\end{array}$ \\
\hline Interaksi & $\begin{array}{l}\text { Interaksi antar siswa dalam diskusi berjalan cukup } \\
\text { baik. }\end{array}$ \\
\hline Perhatian dalam & $\begin{array}{l}\text { Perhatian siswa pada masing-masing kelompok tampak } \\
\text { pelum optimal terutama saat diskusi di dalam } \\
\text { kelompok. Masih terdapat siswa yang tidak terlibat } \\
\text { dalam diskusi. }\end{array}$ \\
\hline Mengajukan pertanyaan & $\begin{array}{l}\text { Beberapa siswa cukup antusias mengajukan } \\
\text { pertanyaan kepada guru, namun masih ada siswa yang } \\
\text { kebingungan terhadap pertanyaannya sendiri, karena } \\
\text { permasalahan yang diberikan tidak dapat dikerjakan } \\
\text { oleh semua anggota kelompok. }\end{array}$ \\
\hline Menjawab pertanyaan & $\begin{array}{l}\text { Jawaban atau tanggapan terhadap pertanyaan dalam } \\
\text { diskusi kelas hanya dilakukan oleh anggota kelompok } \\
\text { yang menyajikan di depan kelas. Sedangkan siswa lain } \\
\text { tidak terlihat aktif dalam memberikan tanggapan. }\end{array}$ \\
\hline
\end{tabular}


Tabel 3 memperlihatkan kualitas aktivitas belajar siswa yang terjadi pada siklus I. Secara umum kegiatan pembelajaran telah berlangsung baik namun masih terdapat kelemahan-kelemahan. Kelemahan tersebut diperoleh berdasarkan kegiatan refleksi.

Tahap See, setelah kegiatan pembelajaran berakhir, guru model dan para observer melakukan kegiatan refleksi. Hasil refleksi pada siklus I dari penerapan pembelajaran dengan model pembelajaran problem solving belum memuaskan. Beberapa hal yang menjadi perhatian untuk dilakukan perbaikan adalah aktifitas siswa dalam melakukan pemecahan masalah, kreativitas mengerjakan penyelesaian permasalahan, dan hasil belajar siswa. Siswa dalam melakukan pemecahan masalah masih kurang terstruktur dan kurang mengevaluasi kembali penyelesaian permasalahan yang dilakukan sehingga masih terdapat kesalahan. Aktifitas siswa kurang memuaskan, masih terdapat siswa yang tidak mengikuti kegiatan pembelajaran. Kerja sama antar siswa pada kelompok-kelompok tertentu belum berjalan dengan baik. Masih terdapat siswa yang berkemampuan baik/pintar tidak mau berbagi atau membantu temannya yang mengalami kesulitan. Sedangkan siswa yang kemampuan akademiknya kurang juga tidak mau untuk bertanya kepada teman maupun kepada guru. Di samping itu sebagian besar siswa lebih banyak melihat penyelesaian berdasarkan buku pegangan, dan tidak menanyakan bagaimana mengerjakan soal. Hasil ini memperlihatkan bahwa siswa belajar hanya untuk dapat mengerjakan tugas dan tidak belajar tentang bagaimana mengerjakan penyelesaian permasalahan dengan metode/cara yang lain atau mencari penyelesaian dengan metode yang baru. Hal ini yang mengakibatkan siswa di luar kelompok penyaji tidak mampu untuk memberikan tanggapan terhadap permasalahan dalam diskusi. Sedangkan untuk diskusi kelas secara umum sudah berjalan baik, walaupun siswa yang terlibat secara aktif masih sedikit.

\section{B. Hasil Penelitian Siklus II}

Secara garis besar hasil refleksi pada siklus I, menunjukkan adanya kelemahan, yaitu: (1) kualitas penyelesaian permasalahan yang dilakukan siswa masih kurang terstruktur dan kurang terperinci, hal ini menunjukkan bahwa kemampuan elaborasi (elaboration) siswa masih lemah, (2) aktivitas siswa dalam diskusi masih didominasi beberapa siswa saja/tidak merata terutama distribusi pengajuan masalah dan tanggapan terhadap permasalahan, (3) kerja sama siswa dalam kelompok belum optimal.

Tahap plan, pada siklus II diarahkan pada strategi perbaikan yang lebih ditekankan pada aspek-aspek berikut: (1) penyelesaian/pemecahan permasalahan dalam mengerjakan tugas kelompok, tes awal dan tes akhir supaya lebih terstruktur, memberikan permasalahan yang menuntut jawaban terperinci, permasalahan yang mempunyai banyak penyelesaian, dan memberikan arahan/permasalahan yang menuntun siswa untuk mengevaluasi kembali hasil pekerjaannya, terutama berkaitan dengan penyelesaian permasalahan yang sudah dikerjakan, (2) mengefektifkan peran guru model untuk memberikan arahan bagi pemerataan keterlibatan siswa dalam diskusi dengan jalan mengarahkan jalannya diskusi, (3) memberikan penekanan pada kerja sama antar kelompok sehingga terjadi pertukaran pengetahuan antar siswa.

Tahap do, kemampuan siswa dalam pemecahan masalah pada siklus II sudah ada peningkatan. Berdasarkan hasil pemeriksaan terhadap tugas-tugas dalam lembar kerja peserta didik (LKPD), tes awal dan tes akhir terutama dalam kemampuan 
berpikir kreatif matematis siswa dalam menyelesaikan soal-soal yang diberikan sudah mengalami peningkatan. Sebagian besar siswa dalam melakukan pemecahan masalah sudah lebih terstruktur mulai dari visualisasi permasalahan sampai dengan melakukan evaluasi atau meneliti kembali hasil penyelesaian terhadap masalah yang bersangkutan. Pemecahan masalah yang terstruktur ini memberikan dampak pada peningkatan rata-rata nilai tes hasil belajar pada siklus II (dari 63,31 pada siklus I menjadi 74,52 pada siklus II).

Kualitas proses pembelajaran siklus II diamati dalam bentuk aktivitas siswa di kelas. Aktivitas siswa sudah mengalami peningkatan dibandingkan dengan siklus I. Data observasi aktivitas siswa pada siklus II disajikan pada tabel 4.

Tabel 4. Aktivitas siswa pada siklus II

\begin{tabular}{ll}
\hline \multicolumn{1}{c}{ Parameter } & \multicolumn{1}{c}{ Deskripsi } \\
\hline Mengerjakan tugas & $\begin{array}{l}\text { Semua kelompok mengerjakan tugas secara } \\
\text { terstruktur dan utuh. }\end{array}$ \\
\hline Kerjasama kelompok & $\begin{array}{l}\text { Semua kelompok menunjukkan kerja sama yang } \\
\text { baik, hal ini tampak saat diskusi kelas, tidak ada lagi } \\
\text { dominasi oleh salah seorang anggota kelompok } \\
\text { tertentu. Pembagian tugas pada masing-masing } \\
\text { individu dalam kelompok sudah terlihat. }\end{array}$ \\
\hline Interaksi & Interaksi antar siswa dalam berdiskusi berjalan baik. \\
\hline Perhatian dalam pembelajaran & Perhatian siswa sangat optimal dalam semua proses \\
\hline Mengajukan & \multicolumn{2}{|c}{} \\
pertanyaan & $\begin{array}{l}\text { Siswa sangat antusias mengajukan pertanyaan } \\
\text { terutama menyangkut perhitungan matematisnya. }\end{array}$ \\
\hline Menjawab pertanyaan & $\begin{array}{l}\text { Sebagian besar siswa sudah mau terlibat dalam } \\
\text { memberikan jawaban atau tanggapan terhadap } \\
\text { permasalahan yang diberikan. }\end{array}$ \\
\hline
\end{tabular}

Tabel 4 memperlihatkan kualitas aktifitas belajar siswa yang terjadi pada siklus II. Secara umum kegiatan pembelajaran telah berlangsung sesuai dengan yang diharapkan.

Tahap see. Hasil refleksi pada siklus II, hasil pekerjaan siswa dalam penyelesaian permasalahan yang diberikan sudah lebih terstruktur, kemampuan berpikir kreatif matematis dalam mengerjakan tugas-tugas sudah mengalami peningkatan terlihat dari penyelesaian permasalahan yang dilakukan dengan berbagai cara penyelesaian. Masih terdapat kesalahan pada perhitungan secara matematis. Aktivitas siswa dalam siklus II sudah berada pada kategori baik. Hal-hal yang mengalami peningkatan pada siklus II ini diantaranya adalah adalah kerjasama antar anggota dalam kelompok, interaksi yang terjadi antar sesama siswa dan juga antara siswa dengan guru, hampir semua siswa sudah aktif untuk bertanya dan menjawab dalam diskusi kelas. Sehingga aktivitas siswa mengalami peningkatan yang sangat berarti jika dibandingkan dari aktivitas yang terjadi pada siklus I. Hasil penelitian ini sejalan dengan penelitian yang dilakukan oleh Harjono, Gunada, Sutrio, dan Hikmawati (2018) bahwa penelitian tindakan kelas dengan pola lesson study dapat meningkatkan aktivitas peserta didik dari siklus I sebesar 3,48 (aktif) ke siklus II sebesar 3,70 (aktif). 
Untuk memperkuat hasil penelitian dilakukan kegiatan wawancara yang tidak terstruktur terhadap 9 orang siswa. Berdasarkan hasil wawancara tersebut diperoleh data bahwa $77,8 \%$ siswa memberikan tanggapan bahwa terdapat perubahan cara belajar setelah memperoleh kegiatan pembelajaran berbasis lesson study. Kalau biasanya siswa sekedar menyalin dari buku pegangan menjadi lebih banyak mengerjakan latihan soal-soal dengan cara berdiskusi sesama teman, sehingga dalam diskusi tersebut siswa dapat menemukan banyak permasalahan-permasalahan dalam merencanakan penyelesaian dari suatu permasalahan yang dihadapinya. Hasil ini sesuai dengan skor salah satu aspek pemecahan masalah yaitu merencanakan penyelesaian yang akan digunakan untuk penyelesaian permasalahan. Ini dapat menjadi indikator yang menunjukkan adanya perubahan dalam hal cara belajar siswa. Selain itu, kegiatan pembelajaran yang berbasis lesson study dapat meningkatkan kualitas proses pembelajaran melalui kerjasama antar siswa maupun antara kelompok guru. Kemampuan berpikir kreatif matematis, sebagai akibat dari kegiatan pembelajaran yang menerapkan model pembelajaran problem solving berbasis lesson study, dapat dilihat pada tabel 5.

Tabel 5. N- Gain kemampuan berpikir kreatif matematis

\begin{tabular}{ccc}
\hline \multicolumn{3}{c}{ Kemampuan berpikir kreatif matematis } \\
\hline Siklus I & Siklus II \\
\hline Rata-rata nilai tes awal & 27,54 & 32,63 \\
Rata-rata nilai tes akhir & 68,28 & 76,45 \\
$\mathrm{~N}-$ gain & 0,65 & 0,76 \\
\hline
\end{tabular}

Dari tabel 5, nilai rata-rata awal kemampuan berpikir kreatif siklus I sebesar 27,54 (kurang kreatif) menjadi nilai rata-rata tes akhir 68,28 (kreatif) dengan N-gain sebesar 0,65 (kategori sedang). Sedangkan nilai rata-rata awal kemampuan berpikir kreatif siklus II sebesar 32,63 (kurang kreatif) menjadi nilai rata-rata tes akhir 76,45 (kreatif) dengan $\mathrm{N}$ - gain sebesar 0,76 (kategori tinggi). Dilihat dari nilai rata-rata tes akhir siklus I dan II, serta perubahan $\mathrm{N}$-gain dari 0,65 menjadi 0,76, keadaan ini menggambarkan adanya peningkatan kemampuan berpikir kreatif matematis siswa setelah mendapatkan kegiatan pembelajaran yang menerapkan model pembelajaran problem solving berbasis lesson study.

Kemampuan berpikir kreatif matematis yang diukur didasarkan pada 5 indikator, yaitu (1) kebaruan (novelty), (2) kelancaran (fluency), (3) keluwesan (flexibility), (4) keterperincian (elaboration), dan (5) kepekaan (sensitivity). Berdasarkan hasil analisis dari kelima indikator itu yang paling terlihat peningkatannya adalah aspek kelancaran (fluency), hal ini disebabkan oleh kemampuan siswa dalam menyelesaikan permasalahan dengan bermacam cara penyelesaian. Selain itu pada aspek keluwesan (flexibility) juga terlihat peningkatan kemampuan siswa dalam menyelesaikan permasalahan dengan satu cara atau dengan cara lain yang berbeda. Indikator lain yang juga cukup menonjol peningkatannya adalah indikator keterperincian (elaboration), terlihat hasil pekerjaaan siswa sudah terstruktur dalam proses penyelesaiannya atau terperinci dari analisis permasalahan, merencanakan penyelesaian, menyelesaikan permasalahan, dan memeriksa kembali hasil penyelesaian. Hasil dalam penelitian ini sesuai dengan beberapa penelitian 
sebelumnya yang menemukan bahwa adanya peningkatan kemampuan berpikir kreatif matematis siswa yang mengikuti pembelajaran berbasis masalah open ended (Noer, 2011), dan kemampuan berpikir kreatif berpengaruh positif terhadap kemampuan pemecahan masalah siswa yang menggunakan model problem based learning (Khoiri, Rochmad, dan Cahyono, 2013).

Hasil belajar siswa, pada siklus I dan II selengkapnya dapat dilihat pada tabel 6. Dari data yang diperoleh dapat diketahui bahwa adanya peningkatan nilai rata-rata hasil belajar pada siklus I sebesar 63,31 menjadi 74,52 pada siklus II.

Tabel 6. Hasil belajar siswa pada siklus I dan siklus II

\begin{tabular}{lcc}
\hline & Siklus I & Siklus II \\
\hline Nilai terendah & 52,64 & 63,25 \\
Nilai tertinggi & 76,20 & 82,67 \\
Nilai rata-rata & 63,31 & 74,52 \\
Standar deviasi & 6,91 & 6,10 \\
\hline
\end{tabular}

Tabel 6 memperlihatkan peningkatan nilai rata-rata hasil belajar dari siklus I ke siklus II, hal ini menunjukkan implementasi model pembelajaran problem solving dengan pola lesson study dapat meningkatkan kemampuan berpikir kreatif matematis dan hasil belajar siswa. Seperti yang diungkapkan Gok (2014) bahwa model pembelajaran problem solving memberikan pengalaman langsung dalam memecahkan permasalahan yang dihadapi, dan problem solving virtual lab dapat meningkatkan kemampuan pemecahan masalah siswa (Sutarno, Setiawan, Suhandi, Kaniawati, dan Putri, 2017). Hasil penelitian ini sejalan dengan penelitian yang dilakukan Cari, Sunarno, dan Rahono, (2014), Sijabat, Motlan, dan Derlina. (2016) yang menyatakan bahwa model pembelajaran problem solving berpengaruh terhadap peningkatan hasil belajar. Implementasi model pembelajaran problem solving dengan pola lesson study sangatlah penting sebagai inovasi pendidikan untuk mengatasi permasalahan-permasalahan dalam pembelajaran.

\section{SIMPULAN DAN SARAN}

Hasil penelitian ini, dapat disimpulkan bahwa penerapan model pembelajaran problem solving berbasis lesson study dapat: (1) meningkatkan kemampuan berpikir kreatif matematis siswa dari kurang kreatif menjadi kreatif, (2) dapat meningkatkan hasil belajar, (3) dapat mengubah cara belajar siswa menjadi lebih memahami dan dapat menerapkan pada berbagai masalah, dan (4) dapat meningkatkan aktivitas belajar siswa.

Berdasarkan hasil yang telah diperoleh disarankan kepada guru untuk dapat selalu berinovasi dalam meningkatkan kualitas pembelajaran melalui kolaborasi dengan guru-guru lainnya, baik yang bernaung di satu sekolah maupun dalam lingkup di luar sekolah. Lesson study dapat dijadikan sebagai sarana untuk pengembangan profesionalisme guru secara berkelanjutan. 


\section{DAFTAR PUSTAKA}

Anwar, N. M., Aness, M., and Khizar, A. 2012. Relationship of Creative Thinking with Academic Achievements of Secondary School Students. International Interdisciplinary Journal of Education, Vol. 1(3) : 12-24.

Ayas, M.B., and Sak, U. 2014. Objective Measure of Scientifics Creativity: Psychometric Validity of the Creative Scientific Ability Test. Elsevier: Thinking Skills and Creativity, Vol. 13(1) : 195-205.

Cari, Sunarno, W., dan Rahono, D. 2014. Pembelajaran Fisika dengan Pendekatan Problem Solving Melalui Metode Demontrasi dan Eksperimen untuk Meningkatkan Motivasi dan Hasil Belajar Siswa. Jurnal Inkuiri, Vol. 3(3) : 7585.

Cox, A.J. and Junkin, W.F. 2002. Enchaned Student Learning in The Introductory Physics Laboratory. Physics Education, Vol. 32 (1) : 1-8.

Gok, T. 2014. Students' Achievement, Skill and Confidence in Using Stepwise Problem-Solving Strategies. Eurasia Journal of Mathematics, Science \& Technolog Education, Vol. 10(6) : 617-624.

Goodson, L, FJ. King, and Rohani, F. 2015. Improving Student's Higher-Order Thinking Competencies, Including Critical Evaluation, Creative Thinking, and Reflection on Their Own Thinking. (Level, Declarative Knowledge, Plan, Quality Enhancement). Research in Science Education.

Harjono, A., Gunada, IW, Sutrio, dan Hikmawati. 2018. Penerapan Advance Organizer dengan Model Pembelajaran Ekspositori Berpola Lesson Study untuk Meningkatkan Hasil Belajar Peserta Didik. Jurnal Pendidikan Fisika dan Teknologi, Vol. 4(1) : 141-150.

Hikmawati, Kesipuddin, dan Rahayu, S. 2018. Analisis Hasil Belajar Kognitif Mahasiswa Pada Perkuliahan Strategi Pembelajaran Fisika Berpola Lesson Study. Jurnal Pendidikan Fisika Lensa, Vol. 2(1) : 179-185.

Hu, W., Shi, QZ., Han, Q., Wang, X., and Adey, P. 2010. Creative Scientific Problem Finding and Its Developmental Trend. Creativity Research Journal, Vol. 22 (1) : 46-52.

Khoiri, W., Rochmad, dan Cahyono, A.N. 2013. Problem Based Learning Berbantuan Multimedia dalam Pembelajaran Matematika Untuk Meningkatkan Kemampuan Berpikir Kreatif. Unnes Journal of Mathematics Education, Vol. 2(1) : 114-121.

Newmann, F.M., and Wehlage, G.G. 1993. Five Standards of Authentic Instruction. Educational Leadership, Vol. 50(7) : 8-12.

Noer, S.H. 2011. Kemampuan Berpikir Kreatif Matematis dan Pembelajaran Matematika Berbasis Masalah Open-Ended. Jurnal Pendidikan Matematika, Vol. 5(1) : 104-111.

Nugraha, T.S. dan Mahmudi, A. 2015. Keefektifan Pembelajaran Berbasis Masalah dan Problem Posing Ditinjau dari Kemampuan Berpikir Logis dan Kritis. Jurnal Riset Pendidikan Matematika, Vol. 2(1) : 107-120.

Nuryanti. 2016. Peningkatan Kemampuan Komunikasi dan Berpikir Kritis Matematis Melalui Model Kooperatif STAD dan Murder. Jurnal Pengajaran MIPA, Vol. 21(1) : 9-13.

Rahayu, P., Mulyani, S., dan Miswadi, S.S. 2012. Pengembangan Pembelajaran IPA Terpadu dengan Menggunakan Model Pembelajaran Problem Based Melalui Lesson Study. Jurnal Pendidikan IPA Indonesia, Vol. 1(1) : 63-70. 
Risnanosanti. 2010. Kemampuan Berpikir Kreatif Matematis dan Self Efficacy terhadap Matematika Siswa Sekolah Menengah Atas (SMA) melalui Pembelajaran Inkuiri. Disertasi tidak diterbitkan. Bandung: Universitas Pendidikan Indonesia.

Saragih, S., and Napitupulu, E. 2015. Developing Student-Centeres Learning Model to Improve High Order Mathematical Thinking Ability. Canadian Center of Science and Education, Vol. 8(6) : 104-112.

Sari, I.P., dan Yunarti, T. 2015. Open-ended Problems untuk Mengembangkan Kemampuan Berpikir Kreatif Siswa. Makalah Pada Seminar Nasional Matematika dan Pendidikan Matematika Universitas Negeri Yogyakarta, Yogyakarta, 2015. Hal: 315-320. ISBN. 978-602-73403-0-5.

Sharma, Y. 2014. The Effects of Strategy and Mathematics Anxiety on Mathematical Creativity of School Students. International Electronic Journal of Mathematics Education, Vol. 9(1) : 25-37.

Shriki, A. 2010. Working Like Real Mathematicians: Developing Prospective Teacher's Awareness of Mathematical Creativity Through Generating New Concepts. Educational Studies in Mathematics. 73 : 159-179. [Online]. Tersedia: https://doi.org/10.1007/s10649-009-9212-2.

Sijabat, A., Motlan, dan Derlina. 2016. Pengaruh Model Pembelajaran Problem Solving dan Pemahaman Konsep Terhadap Hasil Belajar Fisika Siswa. Jurnal Pendidikan Fisika, Vol. 5(2) : 87-91.

Sriraman, B., and Lee, K.H. 2011. The Elements of Creativity and Giftedness in Mathematics. Rotterdam: Sense Publisher. [Online]. Tersedia : https://www.springer.com/gp/book/9789460914393.

Sunaryo, Y. 2014. Model Pembelajaran Berbasis Masalah untuk Meningkatkan Kemampuan Berpikir Kritis dan Kreatif Matematika Siswa SMA di Kota Tasikmalaya. Jurnal Pendidikan dan Keguruan Universitas Terbuka, Vol. $1(2), 41-51$.

Sutarno, Setiawan, A., Suhandi, A., Kaniawati, I., dan Putri, D.H. 2017. Keterampilan Pemecahan Masalah Mahasiswa dalam Pembelajaran Bandul Fisis Menggunakan Model Problem Solving Virtual Laboratory. Jurnal Pendidikan Fisika dan Teknologi, Vol. 3(2) : 164-172.

Yen, T.S., and Halili, S.H. 2015. Effective Teaching of Higher-Order Thinking (HOT) in Education. The Online Journal of Distance Education and $e$ Learning. Vol. 3(2) : 41-47.

Thomas, A.K. and Thorne, G. 2009. How to Increase Higher Order Thinking. Metarie, LA: Center for Development and Learning. 